\title{
The Effects of Environmental Value Orientations and Experience-Use History on the Conservation Value of a National Park
}

\author{
Ju Hyoung Han ${ }^{1}$, Andy S. Choi ${ }^{2}$ il and Chi-Ok $\mathrm{Oh}^{3, *(1)}$ \\ 1 College of Liberal Arts and Interdisciplinary Studies, Kyonggi University, Suwon-si, \\ Gyeonggi-do 16227, Korea; juhyounghan@kyonggi.ac.kr \\ 2 National Institute of Ecology, Seocheon-gun 33657, Korea; kecc21@hanmail.net \\ 3 Graduate School of Culture, Chonnam National University, Gwangju 61186, Korea \\ * Correspondence: chiokoh@chonnam.ac.kr; Tel.: +82-62-530-4075
}

Received: 15 August 2018; Accepted: 18 September 2018; Published: 20 September 2018

\begin{abstract}
National parks are protected areas where special efforts are taken to conserve wildlife species and their habitats. However, the management of parks presents many diverse challenges. One effective mitigation strategy is understanding and improving the connections between environmental awareness and responsible behavior. This study examined this relationship by integrating the value orientations and environmental attitudes of individuals into the developmental process to understand individual conservation behavioral intentions measured as willingness to pay (WTP). The conceptual framework was constructed on the premise that the WTP is hierarchically developed: first, from value orientations and experience-use history, and, second, from attitudes toward national park management. Mt. Seorak National Park has faced diverse problems, including land use conflict from the development of cable cars and high-speed railroad tunnels through the park, and was chosen as a study site. The data were collected from 800 respondents through an online survey that considered the geographical area of residence. This study employed a confirmatory factor analysis and structural equation modeling along with a contingent valuation method to measure WTP. The findings from the study indicated that WTP was connected to specific dimensions of value orientations, attitudes, and experience-use history. The theoretical and practical implications are also discussed.
\end{abstract}

Keywords: environmental value orientations; conservation value; willingness to pay; experience-use history; attitudes; national parks

\section{Introduction}

With the increasing negative environmental impact of various human activities, considerable attention is being paid to diverse topics of environmentalism to minimize this effect. Environmentalism generally involves the multifaceted aspects of individuals' concerns and actions aimed at protecting the environment. While environmentalism is an umbrella term that includes various forms of grassroots participation and social movements, numerous concepts and variables such as environmental orientations, attitudes, and behaviors are known to play a role in the process of how individuals become environmentalists [1,2]. An attitude-behavior relationship is considered an important part of the human decision-making process and explains why and how humans behave in certain ways. More specifically, environmental attitudes are defined as "a person's general positive or negative feeling toward the natural surroundings of humankind, including air, water, land, wildlife, and the systems existing between the natural environment and human society" and environmentally 
responsible behavior (ERB) is "an action that can occur as a result of a person's environmental attitudes" [3] (p. 155).

According to Stern [4], ERB can contain both impact- and intent-oriented definitions, and the adoption of the latter is critical for researchers to be able to delve into an individual's cognitive system, including their motives, beliefs, and values, to alter and improve their targets. He further noted that ERB could be classified into distinct types, and different sets of causal variables likely shape the types of ERB. His four specific ERB classifications are: (1) environmental activism, defined as enthusiastic participation in environmental organizations and demonstrations; (2) non-activist behaviors in the public sphere, which refers to an individual's support for public policies related to environmental issues such as petitioning on environmental issues and willingness to pay higher taxes for environmental conservation; (3) private-sphere environmentalism, which focuses on the purchase, use, and disposal of personal and household goods and services to minimize negative environmental impacts; and (4) other significant environmental behaviors that can help conserve the environment. As noted above, each type of ERB can be developed heterogeneously depending on individuals and, thus, they can be associated with different causal variables [5].

Incorporating the four types of ERB into a single conceptual model is desirable but probably not feasible given the different causal processes involved in the development of each ERB. Subsequently, this paper deals primarily with non-activity behaviors in the public sphere, more specifically an individuals' conservation value for the protection of national parks, measured using the concept of willingness to pay (WTP). While national parks are protected areas where special human efforts are made to conserve wildlife species and their habitats, park management faces a multitude of challenging issues including lack of funding, invasive species, and land use conflict between conservation and development [6]. Among the diverse mitigation strategies, understanding and improving the connection between environmental awareness and responsible behavior is known to be an important means $[7,8]$. This study examined this relationship by integrating the value orientations and environmental attitudes of individuals into the developmental process to understand the formation of conservation behavioral intentions measured as WTP (i.e., the conservation value).

Although several WTP studies have focused on conservation issues of national parks using diverse non-market valuation studies (e.g., [9-11]), one question that has drawn relatively scant attention is: "why are individuals willing to pay for the conservation of national parks and what factors causally influence their WTP?" This question can be better answered using an interdisciplinary nexus between environmental and resource economics and social psychology. Although economists have recently tried to integrate value-oriented, motivational, and attitudinal factors into their valuation models (e.g., [12,13]), the causal relationships between social psychology driven variables and WTP values need to be further explored.

Several social psychology theories, such as value-belief-norm theory, norm activation theory, and theory of planned behavior, can shed light on explaining ERB. In particular, WTP values (i.e., economic benefits or consumer surplus) are understood as a behavioral intention, and other variables such as value orientations and attitudes are expected to causally influence behavioral intentions, which ultimately predicts behavior $[4,14]$. In other words, the greater is the correspondence between an individual's value orientations and attitudes toward specific behaviors, the more favorable are their attitudes toward environmental and natural resources, and their behavioral intention to engage in conservation behavior is more likely $[13,14]$.

Previous studies have examined the relationships between human value orientations and different types of ERB, including recreational-activity-related ERB (i.e., activity- and site-specific ERB) and general ERB in daily life (e.g., $[15,16])$. In addition, the economic valuation literature focusing on assessing the economic benefits of conserving natural and environmental resources has incorporated social psychology-driven variables as independent variables using regression analysis. The current research is different from previous work, as the concept of WTP (i.e., conservation value) is treated as 
a behavioral intention and is incorporated into the developmental process of how value orientations and experience-use history are causally connected to WTP as a dependent variable.

\section{Research Questions}

This study intended, first, to estimate conservation values using a non-market valuation method and then examine how visitors' value orientations and experience-use history are connected with WTP through their attitudes toward national park management. Individuals were asked to reveal their preferences for conserving the national park, presented as the maximum amount of money they are willing to pay to protect the park. Visitors' economic benefits (i.e., WTP), measured as the conservation value, are closely connected with diverse variables derived from environmental psychology, including value orientations, perceptions, and attitudes. As noted above, value orientations and experience-use history can be considered as key variables in the conceptual model that explain visitors' attitudes and conservation values on a sequential basis. Specifically, four key research questions were examined:

RQ1: Using a non-market valuation method, what are the economic benefits of conserving Mt. Seorak National Park (i.e., WTP)?

RQ2: How are the three dimensions of value orientations related to the three dimensions of attitudes toward national park management?

RQ3: How is experience-use history related to the three dimensions of attitudes toward national park management?

RQ4: How are the three dimensions of attitudes toward national park management related to WTP?

\section{Literature Review}

\subsection{Non-Market Valuation of conservation Values}

Economic values for the protection of national parks are normally measured as willingness to pay (WTP). Benefits from environmentally significant sites such as national parks are normally shared by all community members (i.e., non-excludable), and their activities are not expected to undermine the opportunities of others to enjoy the same benefits (i.e., non-rival). These characteristics of public goods make conservation values very difficult to be quantified because public goods are not traded in the market, and so their price signals are not easily available. Thus, special valuation techniques are required to estimate conservation values, including contingent valuation methods (CVM) and choice experiments. Measured economic values are defined in terms of WTP for a new policy or project for conservation, or for given changes [12,17-20].

WTP is understood as the behavioral intention that represents the stated preferences of consumers in a conditional setting. The stated intention, either in the form of discrete choices (e.g., choice experiments) or in the form of contingent acceptance of the bid amounts, is the behavioral reflection of what individuals might do when the hypothetical situation is provided in reality for specific choices. Thus, various underlying factors of stated preferences need to be incorporated into economic models to derive accurate and reliable WTP estimates, including psychographic and attitudinal latent variables $[12,18,19]$. Conservation values for national parks or ERB are likely to be preceded by environmental value orientations and attitudes.

The rationale for testing the attitude-WTP relationships is well grounded in the theoretical understanding of the choice process. As described by McFadden [21] in his Nobel lecture, and illustrated in Figure 1, economic values are estimated as stated preferences based on the respondents' choices (e.g., bid amounts in CVM). The overall choice process is fundamentally intertwined with past experience, value orientations, motivations, and attitudes. Another important point in Figure 1 is that there might exist complex relationships among experiential and psychographic factors. Consequently, structural models need to be firmly established to examine the causal relationships among value orientations, attitudes toward park management, past experience, and conservation values. 


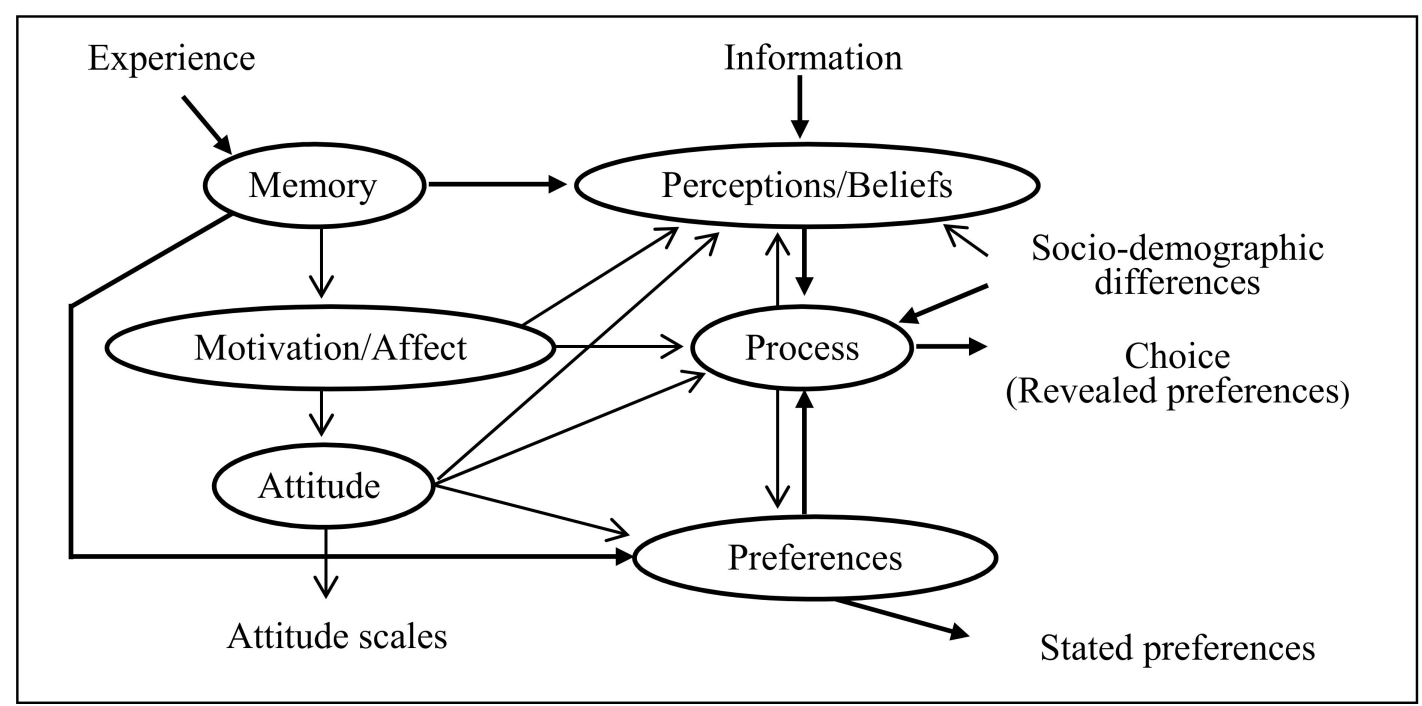

Figure 1. The choice process and latent attitudinal variable (Source: Modified from [21]).

\subsection{Environmental Value Orientations}

As a form of guiding principles in the life of a person [22], values are critical in the formation process of visitor attitudes toward park management. Researchers have recognized that individuals construct their attitudes on the basis of their expectations about how the attitude object (e.g., park management) affects "others", "ecosystem", or "oneself", which they value in their life [23]. For example, a person who values personal benefits above other social or ecological goals may be especially likely to support recreation or tour program development in park management that emphasizes personal goals. Stern and Dietz [23] proposed a set of three classifications for environmental value orientations to understand environmental attitudes and behavior. The three environmental value orientations include altruistic, biospheric, and egoistic value orientations.

First, individuals with the altruistic value orientation would develop their attitudes toward park management based on perceived costs and benefits for others [24]. Researchers explained that individuals who apply the altruistic value orientation experience a sense of moral obligation because they are concerned with the negative consequences that affect others whom they value in their lives [23,24]. Individuals who have a high degree of altruistic value orientation would have more positive attitudes toward park management because they believe that the adverse consequences that are likely to occur to others could be removed or reduced by engaging in appropriate action.

Second, individuals with the biospheric value orientation would develop environmental attitudes based on the perceived costs and benefits for the ecosystem and biosphere as a whole [23]. In other words, individuals with a strong biospheric value orientation believe that, although human needs and desires are still important within a larger and long-term perspective, environmental objects and natural resources have inherent worth, and human benefits are not always the most important $[25,26]$. In a natural resource management context, researchers asserted that for some individuals, the biospheric value orientation may constitute positive environmental attitudes and plays a role in behavioral engagement even if individuals experience conflict with human-centered values [26].

Third, individuals with the egoistic value orientation would consider costs and benefits of the attitude object for themselves personally [23]. Individuals who have a strong egoistic value orientation would protect natural aspects of parks that affect themselves personally or oppose park management if the personal costs are perceived as high. Researchers argue that the egoistic value orientation is an influential factor in the development of environmental attitudes because the outcomes of attitude are most important to the self [27]. Stern and Dietz [23] also demonstrated that egoists, who believe environmental changes threaten them personally, form positive environmental attitudes. 
Several studies have supported the idea that value orientations influence environmental attitudes (e.g., [28-31]). Vaske and Donnelly [32] demonstrated that the biospheric value orientation predicts environmental attitudes toward wildlife preservation. A study by Fairweather, Maslin, and Simmons [29] revealed a positive relationship between biospheric value orientation and attitudes toward ecologically sustainable tourism management in New Zealand. Xu and Fox [33] detailed how the biospheric value influences attitudes toward tourism and environments, and attitudes toward conservation. Researchers have asserted that environmental quality is a public good, and the altruistic value orientation is a necessary motive to develop positive environmental attitudes [23,34]. Laroche, Bergeron, and Barbaro-Forleo [31] supported that those individuals who care about their relationships with others are more likely to be environmentally friendly. Hedlund's [30]'s study established that individuals who value equality, social justice, and peace (i.e., altruistic value orientation) are more likely to have pro-environmental attitudes in their travel decisions. Jansson, Marell, and Nordlund [15] showed that the egoistic value orientation influences environmental attitudes and behavior.

Individuals may hold all of the three value orientations to some degree [23], and when different value orientations are activated in a specific situation, choices are made based on values that are considered to be most relevant to the situation [35]. Accordingly, it was expected that the three environmental value orientations that park visitors hold would influence the three dimensions of visitor attitudes toward national park management to different extents.

\subsection{Experience-Use History}

Experience-use history (EUH) refers to the sum of accumulated experience an individual has within a particular recreational activity or setting [36]. Researchers have examined past experiences with a recreation setting by implying the terminology EUH, and measuring it, for example, through the total number of previous visits to an area $[36,37]$. In terms of recreation resource management, past experience with any outdoor activity or resource setting can influence how recreationists perceive resource attributes or management situations [36]. The differences in past experience may lead to differences in perceptions of physical resources and attitudes toward site management. Watson, Roggenbuck, and Williams [38] supported the idea that EUH leads to perceptual distinctions along with a range of site attributes or attitudinal differences toward site management.

Researchers generally agree that understanding past experience is useful to understand or explain attitudes and behavior [39]. In nature-based tourism and the outdoor recreation context, the natural environment provides individuals with the opportunity to experience nature and gain environmental knowledge $[16,40]$. By coming into contact with wildlife and nature, and gaining knowledge of the environment, individuals have the potential to change their environmental attitudes $[16,40,41]$.

Previous research has attempted to examine the influence of EUH on recreationists' perceptions, preferences, and attitudes. Hammitt and McDonald [36] demonstrated that more experienced river users are more concerned about the resource impact to the attributes of rivers than recreationists with less EUH. Chipman and Helfrich [42] found that highly experienced anglers are likely to prefer to catch and release larger fish, and to favor restricted harvest regulations. McFarlane [43] also found that individuals who are more familiar with the site and campground type prefer more primitive camping sites. Ibitayo and Virden, [37] segmented park visitors into high- and low-experienced groups based on EUH and demonstrated that the level of past experience is related to the perception of depreciative behaviors such as littering, water pollution, noise, and vandalism. Ong and Musa [44] indicated that experienced divers are more likely to engage in responsible behavior, such as avoiding touching and standing on coral, and inspecting regulator readings, than inexperienced divers.

Based on the existing literature presented above, it is expected that EUH can help explain attitudes toward park management. Specifically, it is reasonable to assume that individuals at different levels of EUH would differ in their attitudes toward the management of the site providing those experiences $[45,46]$. However, attitudes toward park management are measured multidimensionally 
in the present study, and the influence of EUH on the different attitudinal dimensions toward park management remains undetermined. To fill this research gap, this study examined the relationships between $\mathrm{EUH}$ and the three dimensions of attitudes toward park management.

\subsection{Attitudes toward Park Management}

Most national parks in the world are under increasing pressures as cornerstones of national and international nature conservation policies and as key providers of nature-based recreational activities $[47,48]$. As visitors are central stakeholders of national parks, an understanding of visitor attitudes toward national park management is a key factor influencing the acceptance and success of protected area management policies [49,50]. Visitor attitudes toward park management refer to their evaluative opinions of park management, which evolves to adapt to the various physical, political, and social environments $[33,51]$. Thus, understanding visitor attitudes toward park management is complex and generally multifaceted.

There has been a growing interest and a variety of approaches among researchers, managers, and decision-makers in examining the dynamics of attitudes toward park management [47]. McCool and Lime [52] outlined six specific themes of national park attitude research; heavy- vs. light-handed management actions, visitor use-limit policies, activity controls, attitudes toward facilities and developments, attitudes toward information, and attitudes toward fees. Huang, Deng, and Zhong [47] measured visitor attitudes toward a national park in China by including roles and functions, management policy regarding recreational use and resource protection, and appropriate use. Woo and Joo [53] claimed that visitor attitudes could be measured with three attitudinal dimensions, stating that affective, participatory, and normative attitudes are the most important aspects of visitors' attitudes toward park management in Korea. Similarly, Arnberger et al. [54] measured visitors' attitudes toward national parks in Austria by including four aspects of attitudes toward park management; these included attitudes toward natural forests, the protection of nature, how positive park management is for recreation and the region, and guidance provided to visitors. $\mathrm{Xu}$ and Fox [33] distinguished three constructs for attitudes; tourism and the environment, conservation, and sustainable tourism development. In summary, on visitors' attitudes toward park management, previous studies have examined all or part of the following three aspects: (1) preservation of nature and life quality of the region; (2) visitor programs; and (3) norms for rules and regulations. This study also employed these three dimensions of visitor attitudes toward park management.

Findings from previous studies indicated that visitors' overall attitudes toward park management are positive, in that the majority of study respondents support park policies and management actions to enforce the protection of park resources. However, those studies also demonstrated variations in visitor attitudes (e.g., [47,55]). For example, Huang, Deng, and Zhong [47] demonstrated that, although a majority of the study participants place a higher priority on protection, there are a certain number of visitors who are still less supportive of rules and regulations for the protection of resources. Lai et al. [55] examined visitor attitudes toward regulations in national parks, and found that there are conservation-oriented, development-orientated, and status quo groups of visitors.

Of particular importance and relevance regarding visitor attitudes toward park management is the identification of the factors that influence these attitudes. Researchers generally agreed that visitors develop their attitudes within a value-based context [5,22,23]. Additionally, previous studies have suggested that understanding an individual's past experience is useful in understanding or explaining their attitudes $[16,36,39,40]$. As a result, this study focused on two important antecedents of attitudes toward park management: value orientations and experience-use history. These are presented in the following sections. Accordingly, we constructed the conceptual model, illustrated in Figure 2, based on a priori assumptions that WTP is hierarchically developed first from value orientations and experience-use history and then from attitudes toward national park management. 


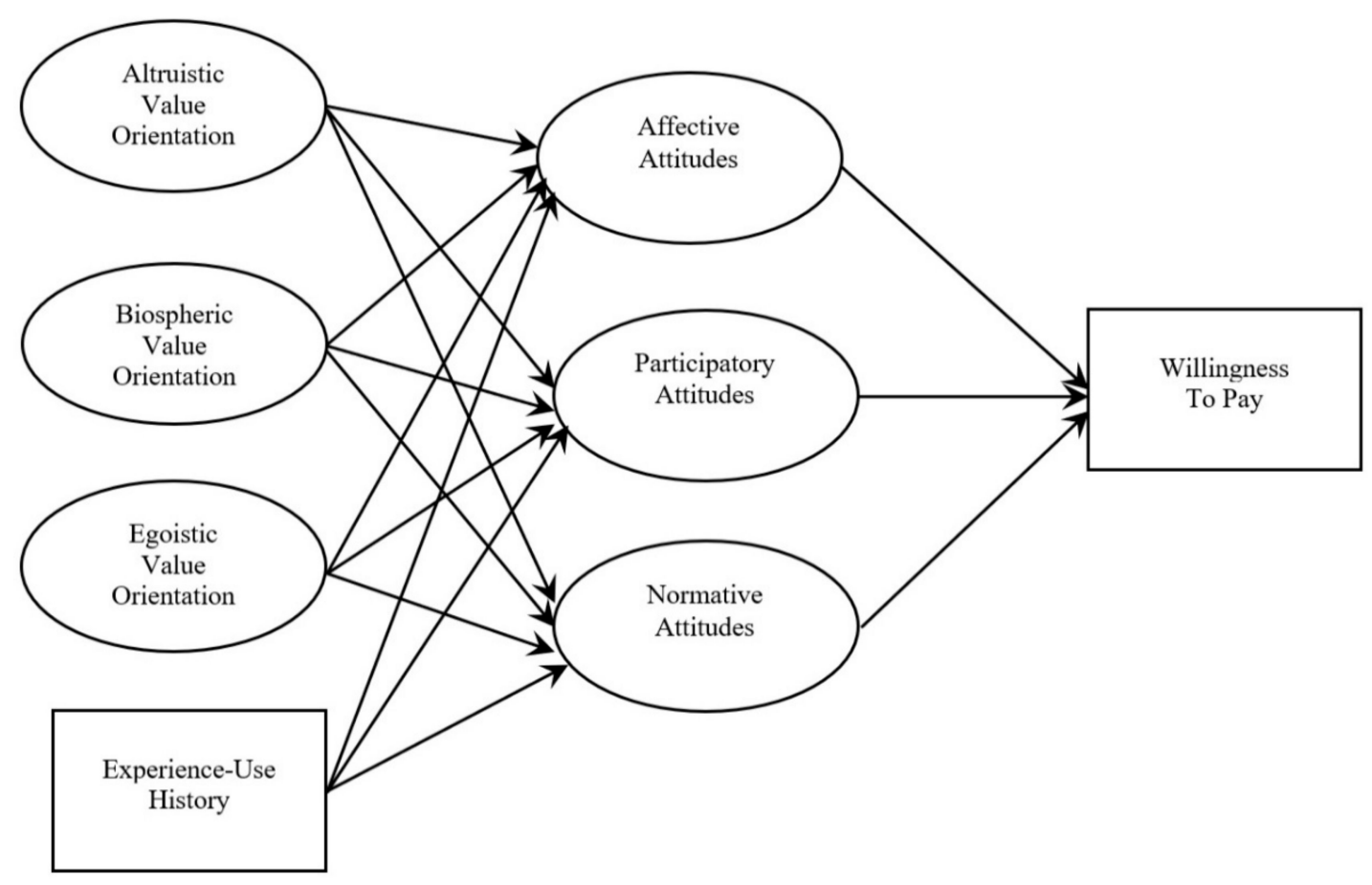

Figure 2. The conceptual model.

\section{Methods}

\subsection{Study Site}

In Korea, a total of 21 protected areas are designated as national parks including Mt. Seorak National Park, and they account for $6.7 \%$ of the total land area in Korea [56]. The Korea National Park Service was established in 1987 to protect the natural and historical park resources and to make them accessible for public use. More than 44 million people visited the national parks in $2016 \mathrm{Mt}$. Seorak National Park was the third most popular national park [56].

Mt. Seorak National Park translates as "big snow mountain" and was first designated a natural monument preservation area in 1965, and in 1973 it became a national park. In 1982, it was designated as a biosphere preservation district by UNESCO. The park is located in northeastern Korea and is spread across four different cities and counties [57]. The main tourism season is fall, with its famous autumn colors. The highest peak of the park is Daecheong-Bong, which reaches 1708 meters (5603 feet), and numerous hiking and climbing courses are available for easy trekking trips and more challenging climbing experiences. According to the statistics of Ministry of Environment of Korea [56], in 2016 the park attracted approximately 3.7 million visitors, including about 400,000 international tourists.

While there have been various problems including overcrowding, waste management, and ecological threats, land use conflicts represented by the development of cable cars and high-speed railroad tunnels have become a major issue in Mt. Seorak National Park. For example, the National Park Commission under the Ministry of Environment rejected the installation of cable cars in 2012 and 2013, but they were recently approved, based on an assessment of the positive economic impact. In addition, in 2008, the construction of a $9.2 \mathrm{~km}$ high-speed railway tunnel through Mt. Seorak National Park was proposed, and the National Park Commission is currently reviewing this proposal.

\subsection{Data Collection}

The study population was confined to individuals who have visited the park at least once in the previous three years to avoid too many "zero" answers due to the nature of inquiring about WTP and other park management-related questions. A national online survey was conducted in October 2016, using a panel recruited by an online survey company in Korea. To select a nationally 
representative sample with respect to the geographical area of residence, we employed a gravity model [58]. According to the model, the total number of trips expected from a particular location to a destination site has an inverse relationship with the squared distance between the two. As such, a sample of 800 respondents was stratified across 15 metropolitan areas, and the assigned number of respondents for each area was randomized according to its gender and age compositions. A total of 4025 individuals visited the survey site, while 19,340 invitations were sent out using one of the largest online panels in Korea. Among the visits, 1651 individuals did not qualify, and 1574 visits were over the quota limits. Then, respondents were screened to select only those who had been to the park. The survey was closed after 800 individuals completed the questionnaire. The instrument was designed carefully with a group of economists and social scientists specializing in outdoor recreation management to ensure readability and improve validity and reliability.

\subsection{Data Analysis and Measurement Instruments}

This study sequentially employed confirmatory factor analysis (CFA) and structural equation modeling (SEM). CFA was conducted to examine whether each of the items was consistently assigned to factors expressed by previous studies. After checking that each of the items was appropriately assigned to a related factor, SEM was conducted to test the structural model with the specification of causal relationships between the latent variables. All data analyses were conducted using SPSS and Mplus.

Value orientations were measured using a scale developed by Schwartz [22]. The scale was developed to capture three different dimensions (i.e., factors) - ecological, altruistic, and egoistic value orientations—and has been used in previous studies (e.g., [23,29-31,33,35]). This scale consists of twelve items using a five-point Likert scale ranging from $1=$ "very unimportant" to 5 = "very important". The results of the CFA demonstrated that the three factors were identified as expected, and the composite reliability index $(0.80-0.87)$ and standardized factor loadings $(0.60-0.91)$ were all satisfactory (Table 1).

Table 1. The results of the confirmatory factor analysis for the latent variables.

\begin{tabular}{|c|c|c|}
\hline Measurement Items & Standardized Factor Loading & t-Value \\
\hline \multicolumn{3}{|l|}{ Environmental Value Orientations } \\
\hline \multicolumn{3}{|l|}{ Altruistic value (composite reliability $=0.80$ ) } \\
\hline Equality (v1) & 0.60 & 17.4 \\
\hline A world at peace (v2) & 0.80 & 25.4 \\
\hline Social justice (v3) & 0.78 & 24.8 \\
\hline Helpful (v4) & 0.66 & 19.7 \\
\hline \multicolumn{3}{|l|}{ Biospheric value (composite reliability $=0.87$ ) } \\
\hline Preventing pollution (v5) & 0.83 & 27.8 \\
\hline Respecting the earth (v6) & 0.87 & 29.9 \\
\hline Unity with nature (v7) & 0.82 & 27.3 \\
\hline Protecting the environment (v8) & 0.80 & 26.7 \\
\hline \multicolumn{3}{|l|}{ Egoistic value (composite reliability $=0.87$ ) } \\
\hline Social power (v9) & 0.68 & 20.9 \\
\hline Wealth (v10) & 0.74 & 23.5 \\
\hline Authority (v11) & 0.91 & 31.8 \\
\hline Ambitious (v12) & 0.83 & 27.3 \\
\hline \multicolumn{3}{|l|}{ Visitors' attitudes toward national park management } \\
\hline \multicolumn{3}{|l|}{ Affective attitudes (composite reliability $=0.76$ ) } \\
\hline I try to understand the issues and concerns of the national park (v13) & 0.69 & 23.9 \\
\hline I try to protect the natural environment of the national park (v14) & 0.72 & 29.0 \\
\hline I try to understand the lifestyle of locals around the national park (v15) & 0.65 & 20.4 \\
\hline My visit to the national park is good for the local people's lives (v16) & 0.60 & 19.5 \\
\hline \multicolumn{3}{|l|}{ Participatory attitudes (composite reliability $=0.64$ ) } \\
\hline I try to participate in education programs when I visit the national park (v17) & 0.64 & 14.8 \\
\hline I try to participate in tour programs when I visit the national park (v18) & 0.61 & 14.1 \\
\hline \multicolumn{3}{|l|}{ Normative attitudes $($ composite reliability $=0.91)$} \\
\hline I try to follow the rules when I visit the national park (v19) & 0.92 & 45.1 \\
\hline I try to follow the conservation guidelines of the national park (v20) & 0.92 & 45.6 \\
\hline
\end{tabular}


Experience-use history was measured with a single item question that assessed how many times the respondents had visited the Mt. Seorak National Park during the last three years. Visitors' attitudes toward national park management were measured with a scale developed by Woo and Joo [53]. This scale consists of twelve items using a five-point Likert scale ranging from 1 = "very unimportant" to $5=$ "very important". The results of the CFA demonstrated that the three factors were identified as expected, and the composite reliability index (0.64-0.91) and standardized factor loadings (0.60-0.92) were all satisfactory (Table 1).

WTP was measured using a contingent valuation method (CVM) with a payment card format. The respondents were asked the following contingent valuation question: "Regardless of whether you have visited Mt. Seorak National Park recently, we are still interested in knowing what you think. Let us suppose that as the use of Mt. Seorak National Park increases, $10 \%$ of natural and environmental resources in the park, such as animals, plants, and landscapes, are damaged. In order to restore damaged resources, how much would your household be willing to pay each year in higher taxes? Your tax payments will be used only to preserve the national park. Check the highest amount that you would be willing to pay for preserving the park." Ten bid values ranging from Korean $\$ 0$ to 100,000 (about \$90) were selected based on a review of previous studies (national park study here) and focus group interviews with other researchers and practitioners.

\section{Results}

The final dataset included 800 respondents and the descriptive statistics illustrating the basic characteristics of the respondents are as follows. Half of the respondents $(50 \%)$ were male, and the mean age was 40 . The median monthly income was between Korean $\$ 4$ million and 4.5 million (equivalent to about $\$ 3800$ as of 21 December 2016). However, 18\% reported that their household income was less than $\$ 2.5$ million (about \$2100) per month and approximately $20 \%$ earned more than $\$ 7$ million (about \$5900). About two-thirds of respondents (68\%) had college or postgraduate education. On average, the respondents had visited Seorak National Park twice during the previous three years, and approximately half (55\%) had visited the park only once. While $18 \%$ had visited the park more than twice, the highest number of visits in the last three years was 50 times.

\subsection{CVM Analysis}

To estimate the mean WTP related to RQ1, the Turnbull lower bound model and the random parameter mixed logit model were employed. The Turnbull estimator was used, as it does not require any statistical assumptions to be made on the distribution of WTP. The methodological simplicity and transparency of the Turnbull estimator assisted with the calculation of the mean WTP and its confidence intervals and allowed the use of an uncomplicated spreadsheet program (see more of the Turnbull estimator from $[59,60])$. The mean WTP of the CVM was estimated as $55829(\$ 4.88)$ and $95 \%$ confidence intervals were also calculated and reported to be between 3408 and The Turnbull estimator as a non-parametric approach, however, does not allow researchers to examine the effects of explanatory variables on WTP, and the use of a parametric approach would be beneficial from this angle. Consequently, a random parameter logit model was also employed. To observe preference heterogeneity, we transformed a single payment ladder question into multiple discrete choice questions [61,62]. Nine non-zero payment levels used in the questions were treated as nine choice questions, where respondents chose between "Yes" to accept the given bid and "No" to reject the proposed change or policy condition. As reported in the literature that has used this approach, the pseudo $\mathrm{R}^{2}$ value was 0.70 , demonstrating an extreme goodness of fit of the economic models. The BID parameter was treated as random, and it was assumed to be normally distributed around the mean. Based on the estimation results, the mean WTP value per person was estimated with $95 \%$ confidence intervals, using the parametric bootstrapping method [63]. The estimated economic value was $\$ 3807$ (\$3.19), and the 95\% confidence intervals were between $\$ 3511$ and 4281 . 


\subsection{Structural Equation Modeling Analysis}

Based on the proposed structural model, the results proved to be a good fit $\left(\chi^{2} / d f=2.60\right.$, $\mathrm{CFI}=0.94, \mathrm{TLI}=0.94, \mathrm{RMSEA}=0.05$ ). All construct reliabilities were greater than 0.7 , implying that all of the constructs were reliable, and the highly significant $t$-values of the factor loadings suggest that the convergent validity of the indicators was satisfactory.

The standardized coefficients of the predictive paths were significant at the 0.05 level, except for the path from the participatory attitudes to conservation, which was significant at the 0.1 level; these are presented in Figure 3. With respect to RQ2, the three value orientations were related to attitudes toward national park management. In particular, while the egoistic value orientation had a positive effect on the participatory attitudes $(\beta=0.25, t=5.7)$, the altruistic value orientation was positively related to the affective $(\beta=0.42, \mathrm{t}=5.1)$ and participatory attitudes $(\beta=0.35, \mathrm{t}=8.0)$. Similarly, the biospheric value orientation had an effect on the affective $(\beta=0.30, t=3.6)$ and normative attitudes $(\beta=0.70, t=25.4)$. In terms of RQ3, experience-use history was positively connected with affective attitudes $(\beta=0.10, t=4.2)$ but negatively related to normative attitudes $(\beta=-0.08, t=-4.9)$. Finally, in terms of RQ4, the affective and participatory attitudes had positive effects on WTP $(\beta=0.08, t=1.9$; $\beta=0.29, \mathrm{t}=6.9$, respectively) but the normative attitudes were negatively related to $\mathrm{WTP}(\beta=-0.11$, $\mathrm{t}=-2.8$ ).

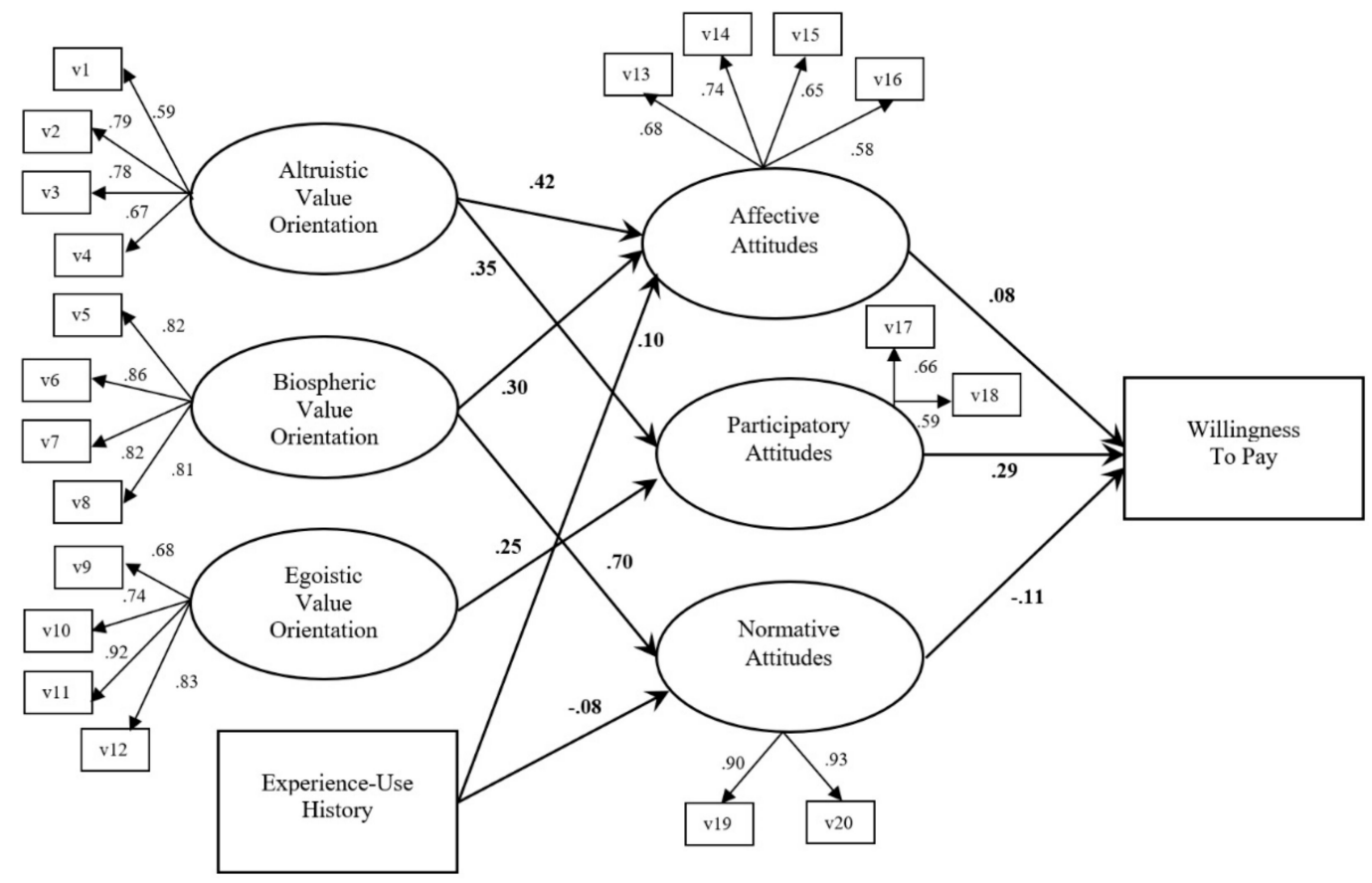

Figure 3. Results of the final structural model.

The results of the indirect and total effects, which can deliver more information on the causal effects, are illustrated in Table 2. The indirect effect of each value orientation on WTP was calculated as the product of the direct effects that lie in the indirect predictive paths between these variables. The total effect can be computed by summing up these indirect effects [64]. The estimated total effect from the altruistic value orientation to WTP had a positive coefficient $(0.692, t=4.7)$, but those from the biospheric value orientation to WTP had a negative coefficient $(-0.242, t=-1.9)$. For the paths between the egoistic value orientation and WTP, the total effect was the same as the indirect effect $(0.340, t=4.3)$. Finally, the total effect of experience-use history on WTP had a positive coefficient $(0.019, t=2.7)$. All coefficients of the total effects were statistically significant at the 0.05 level, apart from the effect between the biospheric value orientation and the WTP, which was significant at the 0.1 level, indicating that there are some important mediating effects. 
Table 2. Direct, indirect, and total effects of the hypothesized paths.

\begin{tabular}{|c|c|c|}
\hline Path & Indirect Effect & Total Effect \\
\hline Altruistic Value Orientation $\rightarrow$ WTP & & $\begin{array}{l}0.692 * * \\
(0.148)\end{array}$ \\
\hline Altruistic Value Orientation $\rightarrow$ Affective Attitudes $\rightarrow$ WTP & $\begin{array}{l}0.170 * \\
(0.096)\end{array}$ & \\
\hline Altruistic Value Orientation $\rightarrow$ Participatory Attitudes $\rightarrow$ WTP & $\begin{array}{l}0.523 * * \\
(0.114)\end{array}$ & \\
\hline Biospheric Value Orientation $\rightarrow$ WTP & & $\begin{array}{l}-0.242 * \\
(0.0129)\end{array}$ \\
\hline Biospheric Value Orientation $\rightarrow$ Affective Attitudes $\rightarrow$ WTP & $\begin{array}{l}0.109 * \\
(0.063)\end{array}$ & \\
\hline Biospheric Value Orientation $\rightarrow$ Normative Attitudes $\rightarrow$ WTP & $\begin{array}{l}-0.351^{* *} \\
(0.127)\end{array}$ & \\
\hline Egoistic Value Orientation $\rightarrow$ WTP & & $\begin{array}{l}0.340^{* *} \\
(0.079)\end{array}$ \\
\hline Egoistic Value Orientation $\rightarrow$ Participatory Attitudes $\rightarrow$ WTP & $\begin{array}{l}0.340^{* *} \\
(0.079)\end{array}$ & \\
\hline Experience-Use History $\rightarrow$ WTP & & $\begin{array}{l}0.019 * * \\
(0.007)\end{array}$ \\
\hline Experience-Use History $\rightarrow$ Affective Attitudes $\rightarrow$ WTP & $\begin{array}{l}0.009 * \\
(0.005)\end{array}$ & \\
\hline Experience-Use History $\rightarrow$ Normative Attitudes $\rightarrow$ WTP & $\begin{array}{l}0.010 * * \\
(0.004)\end{array}$ & \\
\hline
\end{tabular}

Standard errors in parentheses; ${ }^{* *}$ statistically significant at the 0.05 level; ${ }^{*}$ statistically significant at the 0.1 level.

\section{Discussions and Conclusion}

This study integrated the concept of WTP, which measures visitors' conservation value derived from a non-market valuation method and social-psychology-driven variables from psychological theories, into a model that explains the behavioral intention of ERB. More specifically, the proposed conceptual model intended to comprehensively examine whether WTP (i.e., the conservation value) as a proxy variable for ERB is formed by specific dimensions of value orientations, attitudes, and EUH. Other researchers (e.g., [65-67]) noted that it is appropriate to interpret the stated WTP as a behavioral intention of ERB and emphasized the importance of the inclusion of psychological measures (e.g., values and attitudes) in predicting WTP in protected area management contexts. In this way, our findings indicate that conservation values measured as WTP are developed by interacting with variables including value orientations and attitudes, and this corresponds with previous studies $[65,66]$. This study, moreover, expectedly advanced an explanation of a casual developmental process of WTP and made several theoretical and practical contributions.

First, this study can assist researchers in comprehending a hierarchy of cognition [5,23], where WTP is influenced by attitudes, which in turn are affected by value orientations. Most WTP studies previously employed a regression model to explain WTP (e.g., [65-67]), but this does not inspect the holistic causal relationship between WTP and its antecedents. This study attempted to predict and explain the causal mechanisms of WTP by alternatively employing SEM. Accordingly, this study could explain the mixed results of previous findings with respect to the roles of psychological variables in explaining WTP (e.g., [65,66]). Specifically, Ojea and Loureiro [66] reported that the egoistic and altruistic value orientations positively predict WTP but found no significant effect of the biospheric value orientation. Hansla et al. [65] demonstrated that self-transcendence, namely, biospheric and altruistic value orientations, and not egoistic value orientation, is the significant predictor of WTP. The mixed results of previous studies are likely to be due to the omission of attitudes as mediators between value orientations and WTP. According to behavioral psychological theories such as value-belief-norm theory, norm activation theory, and the theory of planned behavior, there is a hierarchy of antecedents of behavior from stable (e.g., values) to specific variables (e.g., attitudes) $[5,23]$. 
That is, environmental value orientations first explain attitudes toward park management, which in turn predict behavioral intention and then behavior. Therefore, this study emphasizes the importance of the inclusion of psychological variables in a hierarchy when explaining and estimating WTP.

Second, the results demonstrated that there are positive but different relationships between specific environmental value orientations and the sub-dimensions of attitudes toward national park management. More specifically, the results verified that visitors who value other people (i.e., altruistic value orientation) and ecosystems (i.e., biospheric value orientation) are more likely to develop positive attitudes toward the natural environment of national parks (i.e., affective attitudes). Likewise, visitors who value ecosystems tended to have more positive attitudes toward following the rules and conservation guidelines of national parks (i.e., normative attitudes). Park visitors whose valued objects are oriented around sources of the self (i.e., egoistic value orientation) and other people tend to have more positive participatory attitudes. The effects of value orientations on environmental attitudes generally support the value-belief-norm theory $[5,23]$ that an individuals' value orientations substantially shape their environmental attitudes. Additionally, the results are consistent with the findings from previous studies that established that the three value orientations are important predictors of environmental attitudes (e.g., [28-31,33]). It was expected that biospheric value orientation significantly predicts affective and normative attitudes, which is consistent with previous studies that have found that the biospheric value orientation is significantly and positively related to various environmental attitudes $[29,32,33,68-70]$. In contrast, it was not expected that the biospheric value orientation does not significantly predict the participatory attitudes. The study results indicated that egoistic value orientation has a positive role, which is inconsistent with the findings of previous studies. Some researchers have asserted that the egoistic value orientation is negatively related to environmental attitudes and behaviors (e.g., [69]), whereas others have supported a positive relationship (e.g., [71]).

The results of the significant and positive relationship between the egoistic value orientation and the participatory attitudes, and the non-significant relationship between the biospheric value orientation and the participatory attitudes could be explained by Schwartz's [22] value orientation categorization. In the categorization, "wealth" belongs to the egoistic value orientation, which further explains the motivations inherent in national park visitors' attitudes toward program participation. Namely, national park visitors are more likely to have positive attitudes toward participating in education programs and tour programs not because they perceive that the attitude objects (i.e., national park programs) matter to the ecosystem and biosphere but because they are concerned about national park degradation, which may have an impact on their or other people's (i.e., the local community living around the parks or human beings in general) health or wealth. Our findings are likely to be related to a premise of the value-belief-norm theory $[5,23]$. That is, national park visitors hold all three value orientations to some degree, and the different issues of park management activate different value orientations, which in turn predicts different attitudes.

Third, another meaningful contribution arises from the associations between the three different dimensions of attitudes and WTP. A specific role of each attitudinal dimension advanced the explanations of WTP in the context of national park management. The study demonstrated that affective and participatory attitudes predict WTP positively, but normative attitudes predict WTP negatively. While the effects of the other attitudes were a priori expected, a negative association between normative attitudes and WTP is a noteworthy finding of this study. There has not been an abundance of studies that have measured the associations between the different attitudinal dimensions and WTP in the context of national park management. Accordingly, it is hard to articulate whether the findings of this study are comparable to those of previous studies. While further research is required, a plausible interpretation can be presented for this negative association. That is, the scale items of normative attitudes have assessed park visitors' attitudes toward rules or regulations that protect the park and these enforced rules and regulations in national parks may impede their independent and responsible use of the resources. If park visitors feel more restrictions are enforced 
and become supportive of the restrictions, they are likely to believe that implementing the rules and regulations is a more effective method of national park management and feel that voluntary conservation support, such as WTP, might be less important. This result seems to be consistent with that of Stern et al. [72], who demonstrated that fewer behavioral restrictions positively affect more enthusiastic environmental behaviors.

Fourth, our study showed that EUH predicts affective attitudes positively. This means that individuals who have visited national parks more number of times are more concerned about the natural environment of the park system, which is consistent with findings from previous research (e.g., $[36,43])$. In contrast, the current research demonstrated that EUH predicts normative attitudes negatively. This negative association likely results from the fact that individuals develop more experiences from visiting national parks, and they become more familiar with the conditions of the national park and thus become less interested in external influences that constrain their freedom of actions such as following the rules or conservation guidelines of the park system [73]. In other words, more experienced visitors might have internalized the norms and become less supportive of enforcing the restrictions. Another possible explanation for this negative association between EUH and normative attitudes could be found in Jett, Thapa, and Ko's [74] study. They denoted that the experience of recreationists has a negative influence on their attitudes toward Florida's boating rules and regulations. They reported this unexpected sign of association by explaining that the restriction in the study context (i.e., vessel speed restriction) was highly publicized, and the exposure to controversial and contentious issues through the media may result in negative attitudes toward boating restrictions among more experienced boaters. In this sense, our study findings might be attributed to the controversial issues of Korean national park regulations, such as access-time restriction and campsite restriction.

Several study limitations are worth noting for future studies. First, the data were collected from visitors to Mt. Seorak National Park. Non-market values of the park contain both use and non-use values, but only a portion of the visitors' use value was measured and reflected in the conceptual model. Therefore, future research is required to include non-use values to measure WTP more comprehensively. In addition, to confirm the study findings, further studies conducted in other national parks would be beneficial to test generalizability. Second, the conceptual model examined the relationships between the value orientations and WTP via park management attitudes. Consequently, some other meaningful variables could be incorporated into the model, such as environmental knowledge, personal norms about environmental management, and place attachment, to better understand the developmental process of conservation behaviors. Third, the link between attitudes and behaviors is not robust although attitudes are significant and important predictors. This study examined national park visitors' behavioral intention using WTP instead of actual behavior, even though individuals' behavioral intention is closely connected with actual behavior, and actual behavior is not equivalent to intention. In addition, it is possible that some responses may be biased because environmental behavior conveys social desirability. To address this, it is suggested that future studies would benefit from including variables directly affecting behavior such as perceived behavioral control and measuring actual behavior. Fourth, WTP was measured with the CVM using a payment card option. This method is certainly advantageous due to its efficiency over other formats such as a dichotomous choice, but this is known to introduce other biases including an anchoring bias [75]. Future research could benefit from using different CVM formats and other non-market valuation methods to help alleviate this type of bias concern. In conclusion, including social-psychology-driven variables such as value orientations, environmental attitudes, and outdoor recreation-oriented variables in a hierarchy of cognition is important and appropriate when integrating the concept of WTP to explain environmentally responsible behaviors, particularly for national park management and conservation.

Author Contributions: Data collection: A.S.C.; Conceptualization: C.-O.O.; Data analysis: C.-O.O., A.S.C.; Writing-Original Draft Preparation: C.-O.O., A.S.C., and J.H.H.

Acknowledgments: It is gratefully acknowledged that the data used in this paper were originally collected as part of a research project at the National Institute of Ecology, Republic of Korea. This study was financially supported 
by Chonnam National University (Grant number: 2017-2904). Also, this work was supported by the Ministry of Education of the Republic of Korea and the National Research Foundation of Korea (NRF-2016S1A5B8914028). The usual disclaimer applies.

Conflicts of Interest: The authors declare no conflict of interest.

\section{References}

1. Hilgenkamp, K. Environmental Health: Ecological Perspectives; Jones and Bartlett Publishers: Boston, MA, USA, 2006.

2. Thoyre, A. Constructing environmentalist identities through green neoliberal identity work. J. Polit. Ecol. 2015, 22, 146-163. [CrossRef]

3. Parker, J.D.; McDonough, M.H. Environmentalism of african americans:An analysis of the subculture and barriers theories. Environ. Behav. 1999, 31, 155-177.

4. Stern, P.C. New environmental theories: Toward a coherent theory of environmentally significant behavior. J. Soc. Issues 2000, 56, 407-424. [CrossRef]

5. Stern, P.C.; Dietz, T.; Abel, T.; Guagnano, G.A.; Kalof, L. A value-belief-norm theory of support for social movements: The case of environmentalism. Hum. Ecol. Rev. 1999, 6, 81-97.

6. Stolton, S.; Dudley, N.; Avcıoğlu Çokçalışkan, B.; Hunter, D.; Ivanić, K.-Z.; Kanga, E.; Kettunen, M.; Kumagai, Y.; Maxted, N.; Senior, J.; et al. Values and benefits of protected areas. In Protected Area Governance and Management; ANU Press: Canberra, Australia, 2015; pp. 145-168.

7. Kaplan, S. New ways to promote proenvironmental behavior: Human nature and environmentally responsible behavior. J. Soc. Issues 2000, 56, 491-508. [CrossRef]

8. Kellert, S.R. The Value of Life: Biological Diversity and Human Society; Island Press: Washington, DC, USA, 1996.

9. Bateman, I.J.; Langford, I.H. Non-users' willingness to pay for a national park: An application and critique of the contingent valuation method. Reg. Stud. 1997, 31, 571-582. [CrossRef]

10. Duffield, J.W.; Neher, C.J.; Patterson, D.A. Economic values for national park system resources within the Colorado river watershed. In Proceedings of the Resource Management Symposium, Scottsdale, AZ, USA, 18-20 November 2008; pp. 123-131.

11. Haefele, M.; Loomis, J.; Bilmes, L. Total economic value of us national park service estimated to be $\$ 92$ billion: Implications for policy. George Wright Forum 2016, 33, 335-345.

12. Choi, A.S.; Fielding, K.S. Environmental attitudes as wtp predictors: A case study involving endangered species. Ecol. Econ. 2013, 89, 24-32. [CrossRef]

13. Spash, C.L.; Urama, K.; Burton, R.; Kenyon, W.; Shannon, P.; Hill, G. Motives behind willingness to pay for improving biodiversity in a water ecosystem: Economics, ethics and social psychology. Ecol. Econ. 2009, $68,955-964$. [CrossRef]

14. Ajzen, I. The theory of planned behavior. Organ Behav Hum. Decis Processes 1991, 50, 179-211. [CrossRef]

15. Jansson, J.; Marell, A.; Nordlund, A. Exploring consumer adoption of a high involvement eco-innovation using value-belief-norm theory. J. Consum. Behav. 2011, 10, 51-60. [CrossRef]

16. Lee, T.H.; Jan, F.-H. The influence of recreation experience and environmental attitude on the environmentally responsible behavior of community-based tourists in Taiwan. J. Sustain. Tour. 2015, 23, 1063-1094. [CrossRef]

17. Kotchen, M.J.; Reiling, S.D. Environmental attitudes, motivations, and contingent valuation of nonuse values: A case study involving endangered species. Ecol. Econ. 2000, 32, 93-107. [CrossRef]

18. Aldrich, G.A.; Grimsrud, K.M.; Thacher, J.A.; Kotchen, M.J. Relating environmental attitudes and contingent values: How robust are methods for identifying preference heterogeneity? Environ. Resour. Econ. 2007, 37, 757-775. [CrossRef]

19. López-Mosquera, N.; Sánchez, M. Theory of planned behavior and the value-belief-norm theory explaining willingness to pay for a suburban park. J. Environ. Manag. 2012, 113, 251-262. [CrossRef] [PubMed]

20. Obeng, E.A.; Aguilar, F.X. Value orientation and payment for ecosystem services: Perceived detrimental consequences lead to willingness-to-pay for ecosystem services. J Environ. Manag. 2018, 206, 458-471. [CrossRef] [PubMed]

21. McFadden, D. Economic choices. Am. Econ. Rev. 2001, 91, 351-378. [CrossRef] 
22. Schwartz, S.H. Universals in the content and structure of values: Theoretical advances and empirical tests in 20 countries. In Advances in Experimental Social Psychology; Academic Press: New York, NY, USA, 1992; pp. 1-65.

23. Stern, P.C.; Dietz, T. The value basis of environmental concern. J. Soc. Issues 1994, 50, 65-84. [CrossRef]

24. Schwartz, S.H. Normative influences on altruism. In Advances in Experimental Social Psychology; Berkowitz, L., Ed.; Academic Press: New York, NY, USA, 1977; pp. 221-279.

25. Needham, M.D. Value orientations toward coral reefs in recreation and tourism settings: A conceptual and measurement approach. J. Sustain. Tour. 2010, 18, 757-772. [CrossRef]

26. Vaske, J.J.; Donnelly, M.P.; Williams, D.R.; Jonker, S. Demographic influences on environmental value orientations and normative beliefs about national forest management. Soc. Nat. Resour. 2001, 14, 761-776. [CrossRef]

27. Hammond, P.B.; Coppock, R. Valuing the Environment; National Academy Press: Washington, DC, USA, 1990.

28. Banerjee, B.; McKeage, K. How green is my value: Exploring the relationship between environmentalism and materialism. Adv. Consum. Res. 1994, 21, 147-152.

29. Fairweather, J.R.; Maslin, C.; Simmons, D.G. Environmental values and response to ecolabels among international visitors to New Zealand. J. Sustain. Tour. 2005, 13, 82-98. [CrossRef]

30. Hedlund, T. The impact of values, environmental concern, and willingness to accept economic sacrifices to protect the environment on tourists' intentions to buy ecologically sustainable tourism alternatives. Tour. Hosp. Res. 2011, 11, 278-288. [CrossRef]

31. Laroche, M.; Bergeron, J.; Barbaro-Forleo, G. Targeting consumers who are willing to pay more for environmentally friendly products. J. Consum. Mark. 2001, 18, 503-520. [CrossRef]

32. Vaske, J.J.; Donnelly, M.P. A value-attitude-behavior model predicting wildland preservation voting intentions. Soc. Nat. Resour. 1999, 12, 523-537.

33. Xu, F.; Fox, D. Modelling attitudes to nature, tourism and sustainable development in national parks: A survey of visitors in China and the UK. Tour. Manag. 2014, 45, 142-158. [CrossRef]

34. Dietz, T.; Stern, P.C.; Guagnano, G.A. Social structural and social psychological bases of environmental concern. Environ. Behav. 1998, 30, 450-471. [CrossRef]

35. De Groot, J.I.M.; Steg, L. Value orientations to explain beliefs related to environmental significant behavior: How to measure egoistic, altruistic, and biospheric value orientations. Environ. Behav. 2008, 40, 330-354. [CrossRef]

36. Hammitt, W.E.; McDonald, C.D. Past on-site experience and its relationship to managing river recreation resources. For. Sci. 1983, 29, 262-266.

37. Ibitayo, O.O.; Virden, R.J. Visitor and manager perceptions of depreciative behaviours in urban park settings. J. Park Recreat. Adm. 1996, 14, 36-51.

38. Watson, A.E.; Roggenbuck, J.W.; Williams, D.R. The influence of past experience on wilderness choice. J. Leisure Res. 1991, 23, 21-36. [CrossRef]

39. Holbrook, M.B.; Hirschman, E.C. The experiential aspects of consumption: Consumer fantasies, feelings, and fun. J. Consumer Res. 1982, 9, 132-140. [CrossRef]

40. Ballantyne, R.; Packer, J.; Falk, J. Visitors' learning for environmental sustainability: Testing short- and long-term impacts of wildlife tourism experiences using structural equation modelling. Tour. Manag. 2011, 32, 1243-1252. [CrossRef]

41. Lee, T.H.; Jan, F.H.; Huang, G.W. The influence of recreation experiences on environmentally responsible behavior: The case of liuqiu island, Taiwan. J. Sustain. Tour. 2015, 23, 947-967. [CrossRef]

42. Chipman, B.D.; Helfrich, L.A. Recreational specializations and motivations of Virginia river anglers. North Amer. J. Fish. Manag. 1988, 8, 390-398. [CrossRef]

43. McFarlane, B.L. Recreation specialization and site choice among vehicle-based campers. Leis. Sci. 2004, 26, 309-322. [CrossRef]

44. Ong, T.F.; Musa, G. Examining the influences of experience, personality and attitude on scuba divers' underwater behaviour: A structural equation model. Tour. Manag. 2012, 33, 1521-1534. [CrossRef]

45. Backlund, E.A.; Hammitt, W.E.; Bixler, R.D. Experience use history and relationship to the importance of substitute stream attributes. Hum. Dimens. Wildl. 2006, 11, 411-422. [CrossRef]

46. Hammitt, W.E.; Backlund, E.A.; Bixler, R.D. Experience use history, place bonding and resource substitution of trout anglers during recreation engagements. J. Leis. Res. 2004, 36, 356-378. [CrossRef] 
47. Huang, Y.; Deng, J.; Li, J.; Zhong, Y. Visitors' attitudes towards China's national forest park policy, roles and functions, and appropriate use. J. Sustain. Tour. 2008, 16, 63-84. [CrossRef]

48. Machlis, G.E. Usable knowledge: A progress report on the NPS social science program. Park Sci. 1996, $20,45-47$.

49. Galloway, G. Psychographic segmentation of park visitor markets: Evidence for the utility of sensation seeking. Tour. Manag. 2002, 23, 581-596. [CrossRef]

50. Müller, M.; Job, H. Managing natural disturbance in protected areas: Tourists' attitude towards the bark beetle in a German national park. Biol. Conserv. 2009, 142, 375-383.

51. Hines, J.M.; Hungerford, H.R.; Tomera, A.N. Analysis and synthesis of research on responsible environmental behavior: A meta-analysis. J. Environ. Educ. 1987, 18, 1-8. [CrossRef]

52. McCool, S.F.; Lime, D.W. Attitudes of visitors toward outdoor recreation management policy. In Proceedings of the National Outdoor Recreation Forum, Tampa, FL, USA, 13-14 January 1988; pp. 401-411.

53. Woo, M.; Joo, H. A study on the influence of optional behavior in recreational forests on visitors' motivation. J. Ind. Econ. Res. 2000, 13, 13-32.

54. Arnberger, A.; Eder, R.; Allex, B.; Sterl, P.; Burns, R.C. Relationships between national-park affinity and attitudes towards protected area management of visitors to the Gesaeuse national park, Austria. For. Policy Econ. 2012, 19, 48-55. [CrossRef]

55. Lai, P.H.; Sorice, M.G.; Nepal, S.K.; Cheng, C.K. Integrating social marketing into sustainable resource management at Padre island national seashore: An attitude-based segmentation approach. Environ. Manag. 2009, 43, 985-998. [CrossRef] [PubMed]

56. Ministry of Environment. National Park Visitors in 2016. Available online: https://www.me.go.kr/home/ web/index.do? menuId=286 (accessed on 19 September 2018).

57. Korea Tourism Organization. Seoraksan National Park. Available online: http://english.visitkorea.or.kr/ enu/ATR/SI_EN_3_1_1_1.jsp?cid=264211 (accessed on 5 July 2018).

58. Zhang, X.; Lu, H.; Holt, J.B. Modeling spatial accessibility to parks: A national study. Int. J. Health Geogr. 2011, 10, 31. [CrossRef] [PubMed]

59. Haab, T.C.; McConnell, K.E. Valuing Environmental and Natural Resources: The Econometrics of Non-Market Valuation; Edward Elgar: Northampton, MA, USA, 2002.

60. Vaughan, W.J.; Rodriguez, D.J. Obtaining welfare bounds in discrete-response valuation studies: Comment. Land Econ. 2001, 77, 457-465. [CrossRef]

61. Sillano, M.; de Dios Ortúzar, J. Willingness-to-pay estimation with mixed logit models: Some new evidence. Environ. Plan. A: Econ. Space 2005, 37, 525-550. [CrossRef]

62. Choi, A.S. Nonmarket values of major resources in the Korean DMZ areas: A test of distance decay. Ecol. Econ. 2013, 88, 97-107. [CrossRef]

63. Krinsky, I.; Robb, A.L. On approximating the statistical properties of elasticities. Rev. Econ. Stat. 1986, 68, 715-719. [CrossRef]

64. Kline, R. Principles and Practice of Structural Equation Modeling, 3rd ed.; The Guilford Press: New York, NY, USA, 2016.

65. Hansla, A.; Gamble, A.; Juliusson, A.; Gärling, T. Psychological determinants of attitude towards and willingness to pay for green electricity. Energy Policy 2008, 36, 768-774. [CrossRef]

66. Ojea, E.; Loureiro, M.L. Altruistic, egoistic and biospheric values in willingness to pay (WTP) for wildlife. Ecol. Econ. 2007, 63, 807-814. [CrossRef]

67. Rosenberger, R.S.; Needham, M.D.; Morzillo, A.T.; Moehrke, C. Attitudes, willingness to pay, and stated values for recreation use fees at an urban proximate forest. J. For. Econ. 2012, 18, 271-281. [CrossRef]

68. Nordlund, A.M.; Garvill, J. Value structures behind proenvironmental behavior. Environ. Behav. 2002, 34, 740-756. [CrossRef]

69. Schultz, P.W.; Gouveia, V.V.; Cameron, L.D.; Tankha, G.; Schmuck, P.; Franěk, M. Values and their relationship to environmental concern and conservation behavior. J. Cross-Cult. Psych. 2005, 36, 457-475. [CrossRef]

70. Wesley Schultz, P.; Zelezny, L. Values as predictors of environmental attitudes: Evidence for consistency across 14 countries. J. Environ. Psych. 1999, 19, 255-265. [CrossRef]

71. Stern, P.C.; Kalof, L.; Dietz, T.; Guagnano, G.A. Values, beliefs, and proenvironmental action: Attitude formation toward emergent attitude objects. J. Appl. Soc. Psych. 1995, 25, 1611-1636. [CrossRef] 
72. Bronfman, N.; Cisternas, P.; López-Vázquez, E.; Maza, C.; Oyanedel, J. Understanding attitudes and pro-environmental behaviors in a Chilean community. Sustainability 2015, 7, 14133-14152. [CrossRef]

73. Sorice, M.G.; Oh, C.-O.; Ditton, R.B. Managing scuba divers to meet ecological goals for coral reef conservation. AMBIO: J. Hum. Environ. 2007, 36, 316-322. [CrossRef]

74. Jett, J.S.; Thapa, B.; Ko, Y.J. Recreation specialization and boater speed compliance in manatee zones. Hum. Dimen. Wildl. 2009, 14, 278-292. [CrossRef]

75. Boyle, K.J. Contingent valuation in practice. In A primer on Nonmarket Valuation; Champ, P.A., Boyle, K.J., Brown, T.C., Eds.; Springer: Boston, MA, USA, 2017; pp. 83-131.

(C) 2018 by the authors. Licensee MDPI, Basel, Switzerland. This article is an open access article distributed under the terms and conditions of the Creative Commons Attribution (CC BY) license (http:/ / creativecommons.org/licenses/by/4.0/). 